Pedagogik Jurnal Pendidikan, Maret 2015, Volume 10 Nomor 1, (1-8)

\title{
PERBEDAAN PENGUASAAN STATISTIKA DAN KEMAMPUAN MENULIS KARYA ILMIAH MAHASISWA PGSD DITINJAU DARI JENIS KELAMIN DAN ASAL DAERAH
}

\author{
Oleh : Bulkani *
}

\begin{abstract}
Abstrak
Penelitian ini bertujuan untuk menguji ada tidaknya perbedaan penguasaan statistika dan kemampuan menulis karya ilmiah pada mahasiswa PGSD UM Palangkaraya, baik secara multivariate maupun univariat, jika ditinjau dari jenis kelamin dan asal daerah mahasiswa.

Metode penelitian yang digunakan adalah deskriptif-komparatif, dengan sampel sebanyak 94 orang. Waktu penelitian adalah pada awal semester genap 2014/2015. Teknik analisis data menggunakan MANOVA.

Dari hasil analisis data disimpulkan bahwa (1).Ada perbedaan penguasaan statistika dan kemampuan menulis karya ilmiah jika ditinjau dari jenis kelamin, dengan nilai $\mathrm{F}=3,993$ yang signifikans pada taraf $\alpha=5 \%(\mathrm{p}=0.022<0.05)$. (2). Ada perbedaan penguasaan statistika dan kemampuan menulis karya ilmiah jika ditinjau dari asal daerah mahasiswa, dengan nilai $\mathrm{F}=7,307$ yang signifikans pada taraf $\alpha=5 \%(p=0.000<0.05)$. (3). Kemampuan menulis karya ilmiah mahasiswa Perempuan lebih baik dari mahasiswa Laki-laki dengan nilai $\mathrm{F}=5,211$ yang signifikans pada taraf $\alpha=5 \%$., (4). Ada perbedaan penguasaan statistika pada mahasiswa jika ditinjau dari asal daerah dengan nilai $\mathrm{F}=4,575$ yang signifikans pada taraf $\alpha=5 \%$. Berdasarkan rerata sampel, maka penguasaan statistika yang paling baik adalah pada mahasiswa yang berasal dari daerah perkotaan, disusul oleh mahasiswa dari daerah urban dan kemudian oleh mahasiswa yang berasal dari pedesaan. (5). Ada perbedaan kemampuan menulis karya ilmiah jika ditinjau dari asal daerah mahasiswa, dengan nilai $\mathrm{F}=11,151$ yang signifikans pada taraf $\alpha=5 \%$ Berdasarkan rerata sampel, maka kemampuan menulis karya ilmiah yang paling baik adalah pada mahasiswa yang berasal dari daerah perkotaan, disusul oleh mahasiswa dari daerah urban dan kemudian oleh mahasiswa yang berasal dari pedesaan.
\end{abstract}

\section{Kata kunci : Penguasaan statistika, kemampuan karya ilmiah}

\section{PENDAHULUAN}

Mata kuliah statistika merupakan salah satu mata kuliah wajib dan penting dalam sistem kurikulum pendidikan di program studi Pendidikan Guru Sekolah Dasar (PGSD) Universitas Muhammadiyah (UM) Palangkaraya. Disebut penting karena mata kuliah ini memberikan dasar-dasar pemahaman penting tentang cara dan teknik penarikan kesimpulan dalam penelitian kuantitatif, sementara penelitian kuantitaif merupakan salah satu jenis penelitian yang banyak dipilih oleh mahasiswa dalam menyusun skripsi untuk penyelesaian tugas akhir. Itulah sebabnya bobot sks mata kuliah Statistika adalah 4 sks, yang kemudian dijadikan prasyarat lulus jika mahasiswa akan mengajukan proposal skripsi.

Selain mata kuliah Statistika, ada beberapa mata kuliah lain yang dijadikan prasyarat dan mahasiswa wajib lulus sebelum menyusun skripsi, yakni mata kuliah Penelitian Pendidikan dan mata kuliah Teknik Penyusunan Karya Ilmiah. Dalam kurikulum PGSD UM Palangkaraya, mata kuliah Statistika ditawarkan pada semester 4, mata kuliah Penelitian Pendidikan pada semester 6, dan mata kuliah Teknik Penulisan Karya Ilmiah pada 
semester 7. Dengan sebaran seperti ini diharapkan bahwa kemampuan mahasiswa dalam penyusunan proposal skripsi akan semakin baik karena kurikulumnya telah disusun secara berjenjang.

Meskipun demikian, adanya variasi dan heterogenitas mahasiswa PGSD UM Palangkaraya, dapat menyebabkan bervariasinya kemampuan dan penguasaan mereka pada mata kuliah mata kuliah tersebut di atas. Adanya variasi jenis kelamin misalnya, dapat mempengaruhi kemampuan menulis karya ilmiah mahasiswa. Bulkani (2014) menemukan bahwa mahasiswi (Wanita) memiliki kemampuan menulis karya ilmiah lebih baik jika dibandingkan dengan kemampuan menulis karya ilmiah mahasiswa (Pria), dengan $\mathrm{F}$ hitung $=6,623$ yang signifikans pada taraf $5 \%$. Selain itu juga ditemukan bahwa kelompok perempuan yang diberi tugas resitasi berupa tugas menyusun proposal penelitian ditambah dengan telaah skripsi, merupakan kelompok yang paling tinggi kemampuan menyusun karya ilmiahnya, disusul oleh kelompok laki-laki yang diberi tugas resitasi berupa tugas menyusun proposal penelitian ditambah dengan telaah skripsi, kelompok perempuan yang diberi tugas resitasi hanya berupa tugas menyusun proposal penelitian, dan terakhir adalah kelompok perempuan yang diberi tugas resitasi hanya berupa tugas menyusun proposal penelitian. Nilai $F$ hitung interaksi antar faktor adalah $\mathrm{F}=$ 6,467 yang signifikans pada taraf $1 \%$.

Penelitian dari Sitorus (2013) menemukan bahwa kemampuan matematika calon mahasiswa baru Universitas Asahan berjenis kelamin perempuan, lebih baik jika dibandingkan dengan calon mahasiswa berjenis kelamin laki-laki, dengan nilai $\mathrm{F}$ hitung $=2,76$ yang signifikans pada taraf $5 \%$. Sedangkan
Azizah Kurnia Wardani (2014) menemukan fakta bahwa peserta didik laki-laki dan perempuan mempunyai perbedaan dalam tahap pemecahan masalah pada soal, perbedaan muncul pada tahap melaksanakan rencana dan memeriksa kembali. Sedangkan untuk tahap memahami masalah dan menyusun rencana tidak ada perbedaan yang signifikan. Fuller (dalam Budiyono, 2002) bahwa perempuan cenderung kurang sukses dalam tes matematika dibandingkan laki-laki. Pandangan Baron dan Cohen (2005) juga relatif sama.

Selain faktor jenis kelamin, mahasiswa PGSD UM Palangkaraya juga berasal dari berbagai daerah, khususnya jika dilihat pada saat mereka lulus dari SLTA. Dalam konteks ini, ada mahasiswa yang dari daerah perkotaan (dari kota Palangka Raya, yang merupakan ibukota provinsi dan cenderung menjadi metropolitan. dari kota di kabupaten (ibukota kabupaten yang cenderung menjadi daerah peralihan atau urban), dan dari pedesaan (misalnya dari kecamatan atau desa di kabupaten). Variasi asal daerah ini juga dapat menyebabkan bervariasinya kemampuan menulis karya ilmiah dan penguasaan mata kuliah lain seperti mata kuliah Statistika. Penelitian Yudi Subianto (2012) menemukan bahwa prestasi belajar siswa yang berasal dari lingkungan masyarakat kota lebih tinggi dari pada prestasi belajar siswa yang berasal dari lingkungan masyarakat desa.. Walaupun beberapa studi menemukan tidak adanya perbedaan hasil belajar matematika antara desa dan kota, seperti penelitian Agung (2012) yang menemukan tidak adanya perbedaan hasil belajar matematika antara peserta didik di kota dan desa yang menerima bantuan siswa miskin di Kabupaten Madiun. . 
Pedagogik Jurnal Pendidikan, Maret 2015, Volume 10 Nomor 1, (1-8)

Dari beberapa uraian di atas maka perlu dilakukan penelitian untuk menjawab beberapa rumusan masalah sebagai berikut (1). Apakah ada perbedaan penguasaan Statistika dan kemampuan menulis karya ilmiah mahasiswa PGSD jika ditinjau dari asal daerahnya ? (2). Apakah ada perbedaan penguasaan Statistika dan kemampuan menulis karya ilmiah mahasiswa PGSD jika ditinjau dari jenis kelamin ? (3). Apakah ada perbedaan penguasaan Statistika dan kemampuan menulis karya ilmiah mahasiswa PGSD jika ditinjau dari interaksi asal daerah dan jenis kelamin ?

\section{METODOLOGI PENELITIAN}

Penelitian dilaksanakan dengan metode deskriptif komparatif, yang dilaksanakan pada awal semester genap 2014/2015. Populasi penelitian adalah seluruh mahasiswa program studi Pendidikan Guru Sekolah Dasar (PGSD) Fakultas Keguruan dan Ilmu Pendidikan (FKIP) UM Palangkaraya, sedangkan sebagai sampel adalah mahasiswa PGSD yang memprogramkan mata kuliah Teknik Penulisan Karya Ilmiah (TPKI) pada semester gasal 2014/2015, yakni sebanyak 94 orang dengan distribusi sebagai berikut :

Tabel 1

Distribusi Sampel Penelitian

\begin{tabular}{|c|c|c|c|}
\hline ASAL DAERAH & Laki-laki & Perempuan & JUMLAH \\
\hline Perkotaan & 10 & 29 & 39 \\
\hline Urban & 11 & 19 & 30 \\
\hline Pedesaan & 9 & 16 & 25 \\
\hline JUMLAH & 30 & 64 & 94 \\
\hline
\end{tabular}

Penelitian ini melibatkan 4 variabel. Variabel terikatnya adalah penguasaan Statistika (Y1) yang diperoleh dari skor tes statistika, dan variabel kemampuan menulis karya ilmiah (Y2) yang tergambar dari dokumentasi nilai kuantitatif mata kuliah Teknik Penulisan Karya Ilmiah yang telah diperoleh mahasiswa pada akhir semester gasal 2014/2015. Sedangkan variabel bebasnya adalah Jenis Kelamin (X1) yang dibedakan menjadi Laki-laki
(A1) dan Perempuan (A2), dan variabel Asal Daerah (X2) yang dibedakan menjadi B1 : Perkotaan B2 : Urban, dan B3 : Pedesaan. Data variabel bebas diperoleh dari dikumentasi.

Untuk menganalisis data, digunakan MANOVA (Multivariate Analisys of Variance) yang dibantu dengan software SPSS dengan syntax sebagaimana ditulis oleh Agung (2006) dan Baso Intang (2015). 
Pedagogik Jurnal Pendidikan, Maret 2015, Volume 10 Nomor 1, (1-8)

\section{HASIL DAN PEMBAHASAN}

Dari hasil pengumpulan data, diperoleh tabel silang analisis data sebagai berikut :

Tabel 2

Tabel Silang Data Penelitian

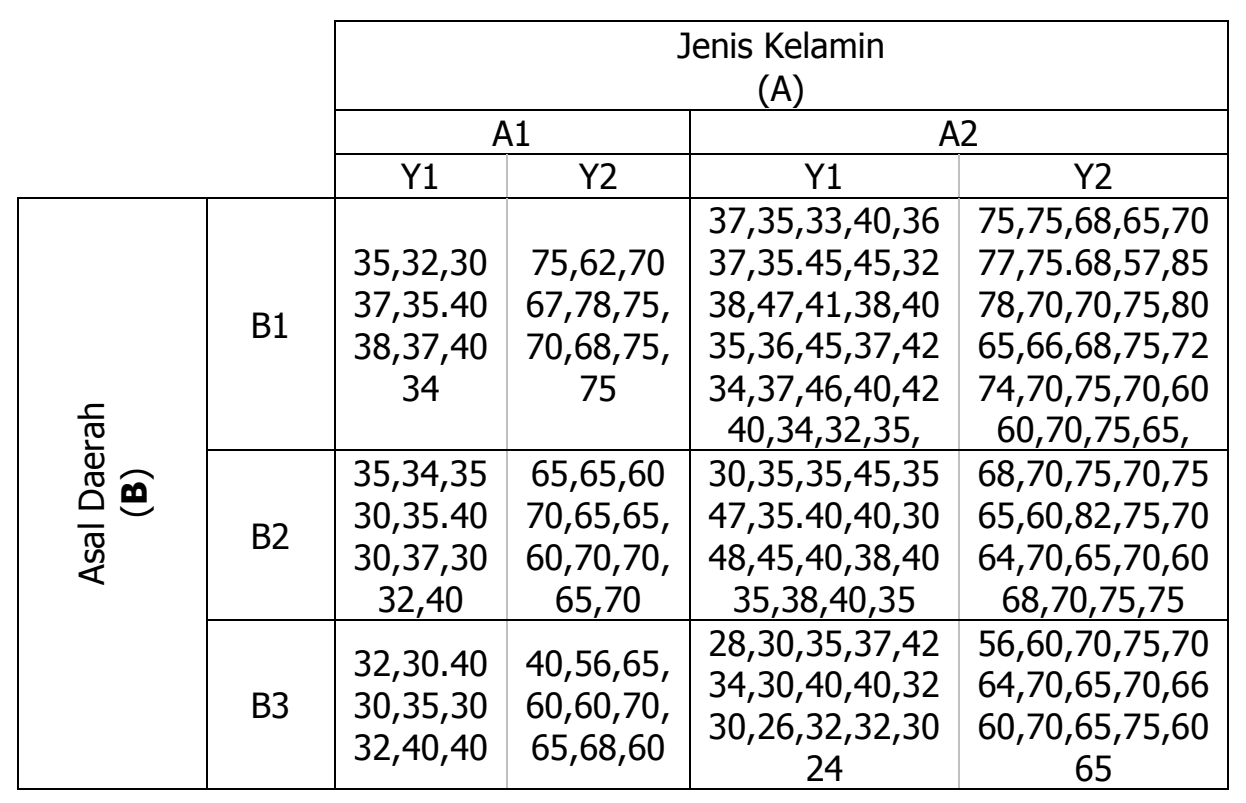

A1: Laki-laki

A2: Perempuan

B1: Asal dari Perkotaan

B2: Asal dari daerah Urban

B3: Asal dari daerah Pedesaan

Y1: Penguasaan Statistika

Y2: Kemampuan Menulis Karya Ilmiah
Dari hasil analisis MANOVA dengan bantuan program SPSS, maka diperoleh tabel hasil analisis deskriptif yang menggambarkan rerata sampel masingmasing kelompok sebagai berikut :

\section{Tabel 3}

Rerata Sampel Masing-masing Kelompok

\begin{tabular}{|l|c|c|c|c|c|c|}
\cline { 2 - 7 } \multicolumn{1}{c|}{} & \multicolumn{2}{c|}{ A1 } & \multicolumn{2}{c|}{ A2 } & TOTAL & TOTAL \\
\cline { 2 - 7 } \multicolumn{1}{c|}{} & Y1 & Y2 & Y1 & Y2 & Y1 & Y2 \\
\hline B1 & 35.80 & 71.50 & 38.41 & 70.79 & 37.74 & 70.97 \\
\hline B2 & 34.37 & 65.91 & 38.47 & 69.84 & 36,97 & 68.40 \\
\hline B3 & 34.33 & 60.44 & 32.63 & 66.31 & 36,03 & 64.20 \\
\hline TOTAL & 34.83 & 66.13 & 36.98 & 69.39 & & \\
\hline
\end{tabular}


Pedagogik Jurnal Pendidikan, Maret 2015, Volume 10 Nomor 1, (1-8)

Sedangkan tabel hasil analisis varians multivariat adalah sebagai berikut :

Tabel 4

Hasil Analisis Varians Multivariat

\begin{tabular}{|ll|r|r|r|r|r|}
\hline Effect & & Vultivariate Tests & \\
\hline Intercept & \multicolumn{1}{c|}{ F } & Df & Error df & Sig.(p) \\
& Pillai's Trace & .994 & $7688.330^{\mathrm{a}}$ & 2.000 & 87.000 & .000 \\
& Wilks' Lambda & .006 & $7688.330^{\mathrm{a}}$ & 2.000 & 87.000 & .000 \\
\hline A & Pillai's Trace & .084 & $3.993^{\mathrm{a}}$ & 2.000 & 87.000 & .022 \\
& Wilks' Lambda & .916 & $3.993^{\mathrm{a}}$ & 2.000 & 87.000 & 022 \\
\hline B & Pillai's Trace & .268 & 6.817 & 4.000 & 176.000 & .000 \\
& Wilks' Lambda & .733 & $7.307^{\mathrm{a}}$ & 4.000 & 174.000 & 000 \\
\hline \multirow{2}{*}{$\mathrm{a}{ }^{*} \mathrm{~b}$} & Pillai's Trace & .105 & 2.441 & 4.000 & 176.000 & .049 \\
& Wilks' Lambda & .897 & $2.429^{\mathrm{a}}$ & 4.000 & 174.000 & .051 \\
& & & & & & \\
\hline
\end{tabular}

Dari Tabel 4 di atas dapat disimpulkan bahwa :

1. Ada perbedaan penguasaan statistika dan kemampuan menulis karya ilmiah jika ditinjau dari jenis kelamin, dengan nilai $\mathrm{F}=3,993$ yang signifikans pada taraf $\alpha=5 \%(\mathrm{p}=0.022<0.05)$

2. Ada perbedaan penguasaan statistika dan kemampuan menulis karya ilmiah jika ditinjau dari asal daerah mahasiswa, dengan nilai $F=7,307$ yang signifikans pada taraf $\alpha=5 \%(\mathrm{p}=$ $0.000<0.05)$

3. Tidak ada perbedaan penguasaan statistika dan kemampuan menulis karya ilmiah jika ditinjau dari interaksi antara jenis kelamin dan asal daerah, dengan nilai $F=2,429$ yang signifikans pada taraf $\alpha=5 \%(\mathrm{p}=0.051>0.05)$

Sedangkan dari hasil uji univariat diperoleh tabel hasil analisis sebagai berikut 
Pedagogik Jurnal Pendidikan, Maret 2015, Volume 10 Nomor 1, (1-8)

Tabel 5

\section{Hasil Analisis Varian Univariat}

Tests of Between-Subjects Effects

\begin{tabular}{|ll|r|r|r|r|r|}
\hline Source & $\begin{array}{l}\text { Dependent } \\
\text { Variable }\end{array}$ & $\begin{array}{r}\text { Type III Sum of } \\
\text { Squares }\end{array}$ & Df & \multicolumn{1}{c|}{$\begin{array}{c}\text { Sean } \\
\text { Square }\end{array}$} & \multicolumn{1}{c|}{$\begin{array}{l}\text { Sig } \\
(\mathrm{p}) .\end{array}$} \\
\hline Corrected Model & $\mathrm{y} 1$ & $513.993^{\mathrm{a}}$ & 5 & 102.799 & 5.072 & .000 \\
& $\mathrm{y} 2$ & $1009.061^{\mathrm{b}}$ & 5 & 201.812 & 5.743 & .000 \\
\hline Intercept & $\mathrm{y} 1$ & 101409.523 & 1 & 101409.523 & 5003.198 & .000 \\
& $\mathrm{y} 2$ & 362824.436 & 1 & 362824.436 & 10324.999 & .000 \\
\hline $\mathrm{A}$ & $\mathrm{y} 1$ & 55.698 & 1 & 55.698 & 2.748 & .101 \\
& $\mathrm{y} 2$ & 183.121 & 1 & 183.121 & 5.211 & 025 \\
\hline $\mathrm{B}$ & $\mathrm{y} 1$ & 185.480 & 2 & 92.740 & 4.575 & .013 \\
& $\mathrm{y} 2$ & 783.699 & 2 & 391.850 & 11.151 & .000 \\
\hline $\mathrm{a}$ * $\mathrm{b}$ & $\mathrm{y} 1$ & 112.811 & 2 & 56.406 & 2.783 & .067 \\
& $\mathrm{y} 2$ & 154.598 & 2 & 77.299 & 2.200 & .117 \\
\hline Error & $\mathrm{y} 1$ & 1783.667 & 88 & 20.269 & & \\
& $\mathrm{y} 2$ & 3092.354 & 88 & 35.140 & & \\
\hline Total & $\mathrm{y} 1$ & 126146.000 & 94 & & & \\
& $\mathrm{y} 2$ & 443257.000 & 94 & & & \\
\hline Corrected Total & $\mathrm{y} 1$ & 2297.660 & 93 & & & \\
& $\mathrm{y} 2$ & 4101.415 & 93 & & & \\
\hline
\end{tabular}

a. $\mathrm{R}$ Squared $=.224$ (Adjusted R Squared $=.180$ )

b. $\mathrm{R}$ Squared $=.246$ (Adjusted R Squared $=.203$ )

Dari Tabel 5 di atas dapat disimpulkan bahwa :

1. Ada perbedaan kemampuan menulis karya ilmiah (Y2) jika ditinjau dari jenis kelamin mahasiswa, dengan nilai $\mathrm{F}=$ 5,211 yang signifikans pada taraf $\alpha=$ $5 \%(\mathrm{p}=0.025<0.05)$. Jika dikaitkan dengan data rerata sampel antar kelompok, maka kemampuan menulis karya ilmiah mahasiswa perempuan lebih baik daripada mahasiswa laki-laki.

2. Ada perbedaan penguasaan statistika (Y1) jika ditinjau dari asal daerah mahasiswa, dengan nilai $\mathrm{F}=4,575$ yang signifikans pada taraf $\alpha=5 \%(p$
$=0.013<0.05)$. Jika dikaitkan dengan data rerata sampel antar kelompok, maka penguasaan statistika yang paling baik adalah pada mahasiswa yang berasal dari daerah perkotaan, disusul oleh mahasiswa dari daerah urban dan kemudian oleh mahasiswa yang berasal dari pedesaan.

3. Ada perbedaan kemampuan menulis karya ilmiah (Y2) jika ditinjau dari asal daerah mahasiswa, dengan nilai $\mathrm{F}=$ 11,151 yang signifikans pada taraf $\alpha$ $=5 \%(\mathrm{p}=0.000<0.05)$. Jika dikaitkan dengan data rerata sampel antar kelompok, maka kemampuan menulis 
karya ilmiah yang paling baik adalah pada mahasiswa yang berasal dari daerah perkotaan, disusul oleh mahasiswa dari daerah urban dan kemudian oleh mahasiswa yang berasal dari pedesaan.

\section{SIMPULAN}

1. Ada perbedaan penguasaan statistika dan kemampuan menulis karya ilmiah jika ditinjau dari jenis kelamin, dengan nilai $\mathrm{F}=3,993$ yang signifikans pada taraf $\alpha=5 \%(\mathrm{p}=0.022<0.05)$.

2. Ada perbedaan penguasaan statistika dan kemampuan menulis karya ilmiah jika ditinjau dari asal daerah mahasiswa, dengan nilai $\mathrm{F}=7,307$ yang signifikans pada taraf $\alpha=5 \%(\mathrm{p}=$ $0.000<0.05)$.

3. Kemampuan menulis karya ilmiah mahasiswa Perempuan lebih baik dari mahasiswa Laki-laki dengan nilai $\mathrm{F}=$ 5,211 yang signifikans pada taraf $\alpha=$ $5 \%$.

\section{DAFTAR PUSTAKA}

Agung, Agus Widi, (2012), Pengaruh Dana Bantuan Siswa Miskin Terhadap Prestasi Belajar pada Siswa Sekolah Menengah Pertama Se-Kabupaten Madiun Tahun 2011/2012, Surakarta : Program Pascasarjana Universitas Negeri Surakarta.

Agung, I Gusti Ngurah, (2006). STATISTIKA: Penerapan Model Rerata-Sel Multivariat dan Model Ekonometri dengan SPSS. Jakarta : Yayasan SAD SATRIA BHAKTI

Azizah Kurnia Wardani (2014), Kemampuan Pemecahan Masalah berdasarkan Perbedaan Jenis Kelamin, Jurnal Pendidikan Matematika STIKIP PGRI Sidoarjo ISSN 2337816699, Vol. 2 Nomor 1.

Baron-Cohen, S., Knickmeyer, R.C., Belmonte, M.K. (2005). Sex Differences in the Brain: Implications for Explaining Autism. Science, Vol. 310

Baso Intang, (2015), MANOVA (bahan kuliah program S3 UNJ), Jakarta : Universitas Negeri Jakarta

Budiyono (2002), Kemampuan Wanita dalam Matematika (Kasus untuk Siswa-siswa Sekolah Dasar). Jurnal Matematika atau Pembelajarannya, Edisi Khusus, Tahun VIII, Juli 2002. Universitas Negeri Malang, Malang. 
Pedagogik Jurnal Pendidikan, Maret 2015, Volume 10 Nomor 1, (1-8)

Bulkani, (2014), Perbedaan Kemampuan Menulis Karya Ilmiah Mahasiawa PGSD UM Palangkaraya ditinjau dari Pemberian Resitasi dan Jenis Kelamin, Jurnal Anterior Volume 13 Nomor 2 Juni 2014, Universitas Muhammadiyah Palangkaraya.

---------, (2010), Penguasaan Metodologi Penelitian pada Mahasiswa PGSD FKIP UM Palangkaraya dengan Menggunakan Pendekatan Pembelajaran Kooperatif TPS, Jurnal Anterior Edisi Khusu Maret 2010, Universitas Muhammadiyah Palangkaraya

Sitorus, Zuriah, (2013), Perbedaan Kemampuan Matematika Calon Mahasiswa Baru Universitas Asahan berdasarkan Jenis Kelamin, Jurnal $\delta$ ELTA, Vol. 1, No. 2

Yudi Subiyanto (2012), Pengaruh Lingkungan Keluarga dan Lingkungan Masyarakat terhadap Prestasi Belajar Siswa Kelas XI Jurusan Otomotif di SMK Piri 1 Yogyakarta, Yogyakarta : Universitas Negeri Yogyakarta 